821.111.08 Дан Џ. 821.163.41.08 Црњански М. https://doi.org/10.18485/sj.2017.22.1.17

НИКОЛА М. БУБАЊА*

Катедра за англистику

Филолошко-уметнички факултет

Универзитет у Крагујевцу

ЧАСЛАВ В. НИКОЛИЋ ${ }^{* *}$

Катедра за српску књижевност

Филолошко-уметнички факултет

Универзитет у Крагујевцу
Оригинални научни рад

Примљен: 04. 07. 2016.

Прихваћен: 15. 12. 2016.

\title{
ПАРАСЛАВИСТИЧКЕ СТУДИЈЕ: ИНТЕРПУНКЦИЈА, ДАН И ЦРЬАНСКИ - ЉУБАВ БЕЗ ГЕНЕРАТИВНОСТИ ${ }^{* * *}$
}

\begin{abstract}
Из позиције паралелних англистичких и славистичких студија, из позиције коју називамо параславистичком, али и против те позиције, у раду се истражују знакови поезије енглеског ренесансног песника Џона Дана у књижевним радовима Милоша Црњанског. С обзиром на документовану наклоност Црњанског према текстовима овог енглеског песника, као и с обзиром на познате синтаксичко-интерпункцијске специфичности поезије и једног и другог, нарочито се покушавају установити паралеле у начинима пунктуирања. Наместо закључка, предочава се сумирање које сугерише да се интерпункција Црњанског може рашчитавати потпуно супротно Дановој, из чега може проистећи и начелно питање о ограничавању исхода компарације њеном намером.
\end{abstract}

Кључне речи: интерпункција, запета, (пара)славистика, Дан, Црњански

\footnotetext{
"nikola.bubanja@gmail.com

*** caslav.nikolic@gmail.com

**** Овај рад је део истраживања која се изводе на пројекту 178018 Друштвене кризе и савремена српска књижевност и култура: наџионални, регионални, европски и глобални оквир који финансира Министарство просвете, науке и технолошког развоја Републике Србије.
} 


\section{УВОД}

Заплет романа Исака Асимова Богови лично почива на контакту „нашег” и „паралелног” универзума. У том паралелном универзуму, названом „парауниверзум”, живе другачији, такозвани „пара-људи”; у паралелном универзуму важе другачији закони физике, па пара-људи једноставним преносом одређеног материјала из пара универзума у „наш” универзум стварају велике количине на изглед потпуно бесплатне енергије. Истина, акумулација те енергије прети да претвори „наше” сунце у супернову и уништи „наш” универзум. Неугодност, која се, међутим, у роману решава успостављањем вишеструких антитетичних размена материјала са другим паралелним универзумима: број два је, најзад, како каже Асимов, ридикулозан број.

Прелаз од употребе назива „паралелни” универзум до назива „пара” универзум пролази глатко, без објашњења: импликација је, ваљда, да је пара само синкопирани облик паралелног.

Паушално, импресионистички, афективни потенцијал речи пара чини се другачијим од оног који има реч паралелни: рекло би се, не улазећи у лингвистичко-статистичке анализе, интервјуе или анкете, да је паралелно самосталнији, неутралнији (математички) појам у свакодневној употреби. Пара се готово не појављује у српском језику као самостални појам (осим кад означава новац или водену пару), звучи интелектуално-полемички и потцртава другост, чак и одбојност онога што означава (парабелум, парагон, парадентоза, парадигма, паразитизам, парализа $\left.{ }^{1}\right)$, нарочито тамо где је његово присуство „префиксно”, јасно издвојено, било полусложеничким карактером речи у којој се налази, било везом са неком српском, а не страном, речју (паравојно, паранормално, параолимпијско).

Строго узев, пара и паралелно деле исту етимологију: паралелно се састоји из para (грчки за поред, покраj) и allelois (грчки за једни друге, изведено из allos, грчки за други), тако да паралелно укупно значи једно поред другог, а nара само поред. Пара, дакле, изоставља неопходност реципроцитета, сличности и изједначености, и тако потенцира разлику и другост.

У овом смислу су српски англисти нешто попут Асимовљевих параљуди из пара-универзума. У овом смислу су аутори овог чланка и намерни ићи ка томе да разменом материјала између славистичке и пара-славистичке области генеришу (учењачку) енергију, бесплатну, иако, вероватно, не и катаклизмичну.

${ }^{1}$ Избор, тенденциозан, дат азбучним редом, из речника страних речи и израза (Вујаклија 1980, 663-666). 


\section{ЦРњАНСКИ И ДАН}

Предочавајући могућности за вредновање књижевности Милоша Црњанског у оквиру компаратистичких истраживања, Бојан Јовић је, у раду „Поетика Милоша Црњанског - два страна утицаја”, подсетио да је „наш” писац, особито након његовог боравка у Паризу 1920-1921. године, проширио своје добро познавање ширег уметничког искуства аустроугарског културног круга и на друге европске средине (Јовић 1996: 83). Указујући на потребу сачињавања обухватније студије о интертекстуалности стваралаштва Милоша Црњанског, Бојан Јовић је Траклов и Флоберов утицај настојао да расветли следствено суматраистичком принципу удвајања живота и књижевности, биографских чињеница и поетике. Суматраистичко приближавање и замењивање противних вредности образује особен књижевни свет, у коме је могуће „упредање и књижевних и биографских момената везаних за друге ауторе а блиских основним Црњансковим животним и књижевним искуствима и погледима" (Јовић 1996: 79). Упореднокњижевно управљање на један естетски прелаз, односно „на чињеницу да је нешто књижевно прешло преко једне језичке границе" (Милосављевић 1991: 349), особито је драгоцено тамо где већ, баш као у случају енглеског песника Џона Дана, постоје искази о поистовећивању једног аутора са другим, упркос различитости њихових језика и упркос временској дистанци.

Писање о енглеским песницима Црњански ће, особито прецизним исказом, одредити у погледу фигуре Џона Дана, енглеског барокног аутора из 17. века: „Ја читам и дивим се Џону Дану, песнику.” (Црњански 2008: 248). Црњански је, као што смо већ другде наводили (Бубања 2007: 127) поменуо Дана још 1920. године, у чланку објављеном у Српском књижевном гласнику. Он је у више наврата поновио да је Дан његов „најмилији енглески песник” (Црњански 1992: 41, 65, 273), а навео је и да је „најлепша песма написана у Енглеској, песма Џон Данова „На двогодишњицу љубави”.” (Црњански 1992: 102).

Црњанског је Дану могла привући склоност крајностима, иконокластици, претеривању, као и извесни утисак слободе који из ових склоности произилази: у Кюижевним новинама, у својој рубрици „Моји енглески песници”, Црњански (1973: 435) каже:

Мене за Џона Дана везује нарочита симпатија. Ја, једну његову песму сматрам да вреди три осталих његових савременика. И Дан је у своје време био одсечан у својим оценама. Кад помиње чувеног минијатуристу Елизабете I, Хиларда (Hilliard), каже: једна рука, или око, које наслика Хилард, вреди читаву историју неког горег сликара. Тако и ја мислим о Џону Дану.

Могуће је да је Црњанског Дану помало привукла и тадашња помодност читања тог песника, и његов статус песника бунтовника - разарача конвенција: 
са дозом задовољства нам Црњански (1992: 41) каже како га је, кад је неком приликом, извесној професорици енглеске литературе говорио о Дану, она зачуђено питала: „забога, Црњански, па ко је то?”

Разлози се могу тражити и из шире перспективе. Зоран Пауновић напомиње да Црњански добро познаје енглеску књижевност, али и енглеску историју, њене токове и јунаке, те да стога у својим есејима о енглеским песницима „Црњански доживљава асимиловану британску културу као нешто своје, нешто што му припада и чему он сам припада" (Пауновић 2012: 20). Џон Дан je, по Милошу Црњанском, први велики дијалектичар енглеске метафизичке поезије, песник велике оригиналности, модерног осећања времена, модерног поетског речника и нових тема.

Ипак, Црњански (2008: 246) као да издваја једну вредност којом Данова поезија надилази поетичке оријентире свог времена:

Очигледно је, међутим, да са годинама, у поезији тог човека, све више одјекује неки звук дубоке меланхолије, која ће бити узрок баш најлепших стихова, у његовој љубавној поезији.

Казивање о меланхолији Данове поезије Црњански 1973. године проширује сликом песника који проповеда о смрти, и краља који слуша о ономе што му, као и Дану, предстоји. Представа великог енглеског песника који у цркви говори о наступајућој, својој и краљевој, смрти, не само да раскрива додатно зрачење у појединим Црњансковим деоницама о цркви Светог Павла и краљу Чарлсу I, него и специфични поступци Црњанског, попут пунктуације, у овим деоницама почињу да зрцале духовним сродством са песником који је о естетском мислио одсечно као „и ја” - са Џоном Даном.

У глави „Секс је корен свега”, бескућни јунак Романа о Лондону из парка Сен Џемса осматра архитектуру Лондона и језеро у парку, који се отварају пред њим као књига прошлих али онтолошки и даље делотворних закона:

Империјалне зграде су, ту, пуне, неких врабаца, који долазе из Шпаније, а на води маестозно плове два пеликана, као они које је краљ Чарлс I, - коме су после одсекли главу, - добио, од оновременог руског посланика. (Црњански 2004: 190)

Ако је парк пробудио „у том човеку осећај неке потребе, да се понаша као да живи у животу у коме је живео, некад, у Русији” (Црњански 2004: 190), онда је буђење потребе да се сопствена егзистенција усклади са искуством које мисао о прошлости представља као пожељније у вези и са приповедачким поступком двоструког пунктуацијског усецања, запетама и цртама, у Рјепнинову оптику референце о погубљењу краља Чарлса I. Парентеза о одсецању главе Чарлсу I потказује како у нарацији Црњанског постоји и дубински ток у коме се лик једног емигранта почиње да огледа у лику једног посеченог краља, као што се лик Црњанског огледа у лику песника који је краљу говорио о смрти. Запете и црте су неми трагови онога што долази после, али не само за Чарлса 
I, него и за Рјепнина. Но не и само то, већ и трагови културноисторијског посредовања фигуре смрти, које ту где запете и црте упредају животопис краља у животопис модерног јунака, приближавају поетике Милоша Црњанског и Џона Дана.

Jep, парентетички рукавац у наведеној реченици као да преводи, оспољава тамни смисао запете након имена „краљ Чарлс I”, а пре речи „добио”, прве иза парентезе. Запете и црте отварају прираст знања о животу краља, па се у резонанцу о краљевом добијању пеликана уткива резонанца о губитку живота. ${ }^{2}$ Поглед Црњанског према цркви Светог Павла у Лондону распознаје празнину као оно у чему врхуни историја модерног света. Ипак, у тишини онога што је нестало, као запету усред бесмисла, као несводљиво, претрајавајуће и хумано зрачење, око Црњанског распознаје књижевност. Понављајући, на крају есеја о Дану, питање о идентитету енглеског песника, Црњански га, не случајно, исписује и запетама пунктуира тако да се у упиту „ко је то” и у одговору на њега једнако огледну и, један у другоме, као два лика истог што ће сва времена наћи, наш Црњански и наш Дан: „Црњански, ко је то, Џон Дан? Црква Св. Павла, као што је познато, изгорела је у прошлом рату. Пожар је обишао само једну малу скулптуру: лик Џона Дана.” (Црњански 2008: 248)

\section{ЗАПЕТА ЦРњАНСКОГ КАО УЗНЕМИРЕЬЕ ДЕТЕРМИНАТИВНОГ СМИСЛА}

Темељно својство песничког идентитета, по Милошу Црњанском, представља унос уметничке тенденције у језик, захваљујући којој књижевни рад постаје естетска формулација (Црњански 2004). Језик Црњанског необична је појава у српској књижевности, особито јер се појављује у хоризонту свиклости „на један врло једноставан језик”. Открива се црњанскијански језик из дубинског осећаја његовог творца да „српски језик може да 'свира', да говори и да буде врло интересантан језик” (Црњански 2004: 690). Препознатљиве запете Црњанског израз су делфијског и модернистичког самоосећања писца:

А има бесвесних момената када поезија говори. Онда ви мећете тачке, и запете, доцније, а пустите да вас носи језик, један занос језика који није нормалан, такорећи. Често се после питам зашто сам тако формулисао реченицу. То нису играчке, то је озбиљна ствар. Ви знате, још давно, у Делфима, сматрало се да је песник опседнут. Па мора да је опседнут, иначе није песник. Кад пишем, на пример, писмо приватно, наравно да мој

\footnotetext{
${ }^{2}$ Рјепнин ће пред растанак са супругом Нађом, „да би прекинуо, пред женом, очај, који га је овога пута, више него икад пре, био обузео", говорити стихове руског песника Гумиљова, наведене управо парентетички, у заградама: „[...] поче, подругљиво, да се смешка и да говори, тихо, руски, стихове Гумиљова, које је волео (Учтиво се понашам према животу, али је међу нама пукао јаз).” (Црњански 2004: 508)
} 
језик није такав, и да моје запете нису такве. Али у поезији су, међутим, врло важне. (Црњански 2004: 689-690)

У тексту „Хазарски вилајет”, професор Александар Јерков (2010: 140) каже да проза Црњанског производи синтаксички удар, дотичући се тако идиосинкразије Црњанског у погледу употребе интерпункцијских знакова и у погледу синтаксичке структуре уопште.

Интересантан је у овом смислу пример четвртог стиха завршне строфе песме „Пролог” из Лирике Итаке, које у првобитном издању из 1919. године не садржи запете: „небо што високо звездано мирише” - међутим, око три деценије касније Црњански додаје запете: небо, што високо, звездано, мирише". Ову интервенцију објашњава потребом да запете које су смисаоно, иако не и графолошки, одувек биле присутне у стиху, сада и физички реализује (Петковић 1996). Новица Петковић сматра да је овим запетама извршена превентивна интервенција у значењу стиха, у смислу спречавања могућности тумачења ових стихова у смислу синестетичног споја неба што звездано мирише, и тако даље.

Међутим, Новица Милић, у текстовима Зарез Црњанског 1 и Зарез Црьанског 2, посматра запету Милоша Црњанског као кантовски монограм и шири естетски елемент текста. Монограм Милић разуме следствено Кантовом становишту у трећој критици, у којој је наглашена иманентна вредност монограма за стваралачку уобразиљу, његова идеограмска несаопштивост изван имагинативног хоризонта, те дакле његова појединачност, непреводивост. Вредност запете као монограма остварује се и изван говора, па је запета нем знак, сентимент одсуства чулног. „А ипак, уметност нам говори тим немим знаком пре сваког његовог превођења или саопштавања у неком другом, са становишта естетског спољашњем низу или говору" (Милић 1996: 57). Откривање монограмског карактера интерпункције унутар синтаксичке структуре показује како постоје могућности којима интерпункција надмашује вредност помоћног средства синтаксе. Уколико се, као у књижевном делу Милоша Црњанског, укрштај интерпункције и синтаксичког поретка испољава у виду притиска интерпункције на синтаксу, у виду „дивљег” пунктуацијског парања, декомпоновања и дерегулисања уобичајених поредака речи, очито је да херменеутичка теза о неодредивости монограма има веома убедљив стваралачки, књижевни аргумент.

Естетски монограм, сматра Милић, уноси неред у једну логичку структуру. Милић наводи наш поглед, дакле, ка позицијама где запета није нужни чинилац „мелодијске ритмизације”, нити „ритмизације смисла, семантичког померања и премештања”, већ се уписивањем запете тамо где је „не мора бити" почиње да испољава вишак у њеним могућностима, вишак што запету ослобађа подређености синтакси. Преступање синтаксичких стандарда, по 
Новици Милићу, не настаје само због вишка значења које се речима не може обухватити, него су, на другој страни, запете у делу Црњанског средство откривања мањка и испуњавања тога мањка. Додирујући се, преко осећања, са читаоцима, текстови Црњанског контакт субјекта и текста одржавају не утврђивањем смисла, него детотализацијом и онеодређивањем смисла.

Зарез у стиху 'Ја видех Троју, и видех све' ('Пролог', Лирика Итаке) управо скупом могућих функција (конклузивне, инклузивне, дисјунктивне) помаже неодлучивост која је потребна да се наговести лутање по значењу, лутање које се потом наговештава као основни смисао, али никада, већ и по значењу које је сабрао у себи, као једини смисао [...]. (Милић 1996: 63)

„Дивља” интерпункција Црњанског отвара само читање баш тако што га непрекидно узнемирава и тако га отвара за естетску димензију. Упућујући на црњанскијанску пунктуацију исказа као на фундаментални поступак којим се линеарно разумевање прекорачује а унивокалност напушта, Новица Милић утврђује како интерпункција Црњанског представља „чинилац индетерминације читања". До разарања норми читања долази заустављањем синтезе, управо помоћу запета, које нашавши се тамо где их ни синтакса ни читаоци не предвиђају ${ }^{3}$ спречавају спрезање деоница смисла и деоница реченице „у неку трећу, 'вишу' идеју... представу". Заустављајући синтезу, интерпункција Црњанског изнова показује „неку од могућности која би се иначе, коначним моделом читања, изгубила" (Милић 1996: 66), а опседајући га нечитљивошћу, својом немошћу, интерпункција призива читаоца да из те немости као из граничног искуства језика перманентно одржава своје стремљење тексту, његовом обухватању.

Такав естетски монограм, каже Милић (1996: 58),

... представља поредак једне несводљивости, и утолико што се отима поретку других низова, што уноси неред у ред речи, чинећи или надодређујући и тај поредак несводљивим, неодредљивим, загонетним, Црњански управо користи интерпункцију у овој дисфункционалној функцији, у својству разградње или рашчињавања синтаксе...

Дакле, интерпункција Милоша Црњанског, посебице запета, дата је у једној иконокластичној изведби, можда и у ширем смислу карактеристичној за Црњанског као аутора. Како наводи Милић (1996: 59), „тематски и интерпретативно се не може извући заједнички именитељ или правило које би се тицало значења" интерпретације Црњанског, јер је она управо замишљена као разградња или макар разигравање значења - као повлачење из онога што Милић назива детерминативним значењем, и стварање мањка значења и смисла који ће водити читаоца искораку ка вишем естетском нивоу смисла и текста и интерпункцијског знака.

${ }^{3}$ Новица Милић упућује и на познат пример прве реченице Дневника о Чарнојевићу: „Јесен, и живот без смисла." 
Другим речима, иако је и код Црњанског могуће и потребно везивати употребу интерпункције за само значење текста, нарочито у смислу његове ритмизације и поетизације, упадљива је иконокластична тежња аутора да својом интерпункцијом унесе неред у значење, мултипликује га и тако створи његов мањак, отварајући могућност постојања трансцендентне интерпункције.

\section{УМЕСТО ЗАКЉУЧКА - СМРТ, КОЈА ЈЕ (САМО) ЗАПЕТА}

Још је МекКероу (1927: 250), како наводи и Ивлин Симпсон (1928: 295) налазио да има врло мало доказа о томе да су елизабетински аутори уопште марили за интерпункцију:

То мало интерпункције што се може наћи у обичним рукописима из шеснаестог и седамнаестог века је заиста веома неконзистентно и ретко иде даље од тачке на крају реченице и већ некакве индикације цезуре у стиховима ... Чини се да расположиви докази показују да је оно мало правила (интерпункције) што је постојало, постојало углавном међу штампарима, и врло је могуће да су она варирала од штампарије до штампарије, како је, уосталом, и данас случај.

Such punctuation as is to be found in ordinary MSS. of the sixteenth and seventeenth centuries is indeed most erratic and seldom goes beyond full stops at the end of most of the sentences and some indication of the caesura in lines of verse... So far the evidence seems to be that such rules as there were existed chiefly among the printers, and it is quite possible that they varied from house to house, as indeed they do still.

Сам Дан (1981: 54) је у песми „Опроштајна реч: о мом имену на прозоpy" (A valediction: of my name, in the window), о свом имену, угравираном на прозору драге, записао:

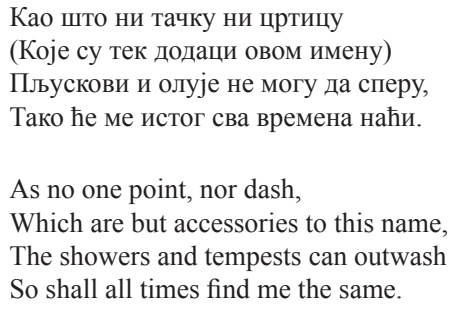

Тачку и иртииу из ове песме, као претпостављене интерпункцијске знакове, песник с једне стране одређује, парентетично, као споредне елементе текста, односно писма, али с друге стране исказује, као каквом басмом, неку врсту обавезе неповредивости његовог записа и пратеће интерпункције.

Без обзира на то да ли су наведени стихови sprezzatura, односно „умеће скривања умећа", заветовање на чување ауторове интерпункције или опис 
уобичајене нехајности времена, времена су, као у инат песми, мењала песниково име, и његове тачке и цртице.

Име му је писано различито (Don, Dun, Dunne) и различито изговарано - данас превладава изговор Дан, а пре само стотину година превладавао је изговор Дон (узгред, и Црњански је овога био свестан и сврстао се у ред оних који су, тада бунтовно, песника звали Дан).

Не бисмо хипотетисали о томе у којој мери је Данова оригинална интерпункција мењана у сачуваним рукописима и првим штампаним издањима песама почев од 1633. године (о томе видети Стингер 2000: LI). Ограничили бисмо се на понављање факта да његове песме углавном нису сачуване у аутографском рукопису. Према данашњем знању, Дановом руком написана остала су нам прозна писма (око 40), неколико посвета у књигама пријатеља и познаника, епитаф жени и једна једина песма - заправо стихована епистола упућена Леди Кери и Госн Есекс Ричу (Стингер 2000: XLIX). Дакле, сачувани рукописи - преко пет хиљада рукописних верзија појединачних песама - већином су преписи (премда су неки аутори сматрали да и међу њима постоје релативно ауторитативни рукописи, попут рукописа Дановог Биатанатоса на основу ког је још Ивлин Симпсон $(1928: 295,300)$ тврдио да је Дан педантно водио рачуна о својој интерпункцији).

Интервенције уредника модерних издања Данове поезије се, међутим, могу документовати. Џон Хејворд (1936: 762) у свом издању Данове поезије и прозе, овако објашњава измену позиције запете у стиху 20 , песме Зеленаштво љубави (Love’s Usury): „Господин Спероу (такође уредник Данове поезије) је предложио ову емендацију, коју сам ја прихватио, и коју оправдава смисао, а која се састоји у томе да се запета премести испред речи највише" (Mr. Sparrow suggested this emendation, which I have adopted, and which the sense justifies, of placing the comma before 'most"').

Хејворд (1936: 762) поздравља измене које је у свом издању Данових песама учинио Херберт Грирсон у стиховима Данове Канонизаиије, где је додао тачку и запету, знак узвика, као и парентезу (заграде). Док се Грирсон, како наводи Редпат (1967: іх), у својим емендацијама Данове интерпункције водио жељом да успостави пунктуирање које би вероватно било идентично Дановом, Смит (1971: 14) је мењао интерпункцију тамо где је сматрао да би збуњивала модерног читаоца. Исто тако, Редпат (1967: ix) је емендирао пунктуирање како би нова интерпункција помогла да се „модерном читаоцу истакне ... пуно значење дате песме" ("to aid in bringing out to a modern reader ... the full meaning of the poem concerned").

Редпат (1967: х) објашњава како је запете на крајевима каткад стихова замењивао двема тачкама или тачком и запетом, јер му се чинило да је „запета имала другачије границе вредности у енглеском шеснаестог и седамнаестог 
века од оних које има данас" ("the comma had different limits of value in sixteenth and seventeenth century English from those which it has today"). Он (Редпат 1967: х) чак брани своје поступке према интерпункцији једном врстом презира према тричарији каква је очито пунктуирање, које, чини се, непотребно ограничава читање:

Оно чему се мора бити веран приликом продуцирања модерног текста, јесте Данова финеса, страст, еволуција аргумената, ритмички дух ... где се мора бирати, далеко је горе бити неверан горе неведеном, неголи систему знакова, који често не показује ништа до шкрипаву прастарост без трунке свог оригиналног, финкционалног живота.

Чак се и у Вариорум издању Данове поезије приступало емендацији интерпункције како би се спречило погрешно читање (Стингер 2000: LIV), односно како би се интерпункцијом присилно интерпретирао смисао.

С обзиром на преко пет хиљада рукописа појединачних песама и 7 штампаних издања само из 17. века, уредници су имали и имају широк дијапазон избора пунктуирања; али ни пет хиљада варијанти понекад није довољно. Хејворд (1936: 763) тако за своје емендације у стиху 35 Данове песме Onроштајна: забрана јадиковања, записује: „смело сам усвојио верзију које нема ни у једном од раних издања и ни у једном рукопису" ("I have boldly adopted the reading which none of the editions or MSS. Give").

Можда као илустрација може послужити и комад Маргарет Едсон, Bucпреност, у коме проучаватељка Данове поезије тврди да је једина поуздана верзија интерпункције стиха Не горди се смрти, она коју даје Хелен Гарднер, у којој после речи смрт уместо узвичника стоји запета (наведено и у Ламонт 2000: 571-572). Она затим објашњава: смрт тако престаје да буде нешто што се глуми на сцени, са знацима узвика, смрт је само запета, пауза; нема ту непремостивих баријера узвичника и тачке зареза, само запета (наведено и у Ламонт 2000: 571-572).

Дакле, Данова интерпункција, у свом сталном настајању, водила се, и даље се води, смислом. Она је творевина других - најпре записивача и преписивача првих рукописа, затим првих штампара, и најзад уредника и проучавалаца. Данова пунктуација је, као можда и најрањивији део било које аутографске грађе, данас алографски паратекстуални елемент са интерпретативном функцијом. Она је врста глосе, фусноте; још и горе, она је водич, мапа, проскрибовано упутство за читање Данове поезије.

Одувек сматрана опскурном и тешко разумљивом (краљу Џејмсу се приписује да је изрекао: стихови др Дана су као путеви господњи - с оне су стране разумевања), Данова се поезија нудила одгонетању, читању изблиза, формалној дисекцији, као и интерпретативној алографској интерпункцији. Ваљда је Т. С. Елиот (1963: 75) био први који је за наводну херметичност метафизичке поезије окривио синтаксу: „треба подвући да је језик ових песника 
по правилу једноставан и чист... с друге стране, структура реченице понекад није ни изблиза једноставна".

Другим речима, где запета Милоша Црњанског разиграва синтаксу и пркоси једнозначју, псеудо-Данова запета је припитомљује, укалупљује. Ако запета Црњанског, дакле, у Лотмановском сукобу система или структура, уноси неред, псеудо-Данова хоће управо да конструише ред. Ако запета Црњанског бежи од онога што Новица Милић назива детерминативним смислом, псеудо-Данова бежи од оног рефлексивног. Ако запета Црњанског може бити кантовски монограм, естетски елемент, дотле се псеудо-Данова можда може успоставити као помоћно средство формалне дисекције или епифаније разумевања. Запета Црњанског је, чини се, пролазила путем, потпуно супротним од Данове: ако је Данова интерпункција утицала на интерпункцију Црњанског, онда је тај утицај могао бити као какав магловити ехо, импресионистички прочитан; или можда ипак као негативан пример, крутост коју треба разиграти, неправда против које се треба борити.

Љубав се не крунише нужно генеративношћу. Параславистичка студија не завршава се нужно почетком, ограничена првобитном намером, спрегнута бесконачно кружним резоновањем.

\section{ЛИТЕРАТУРА}

Бубања 2007: Н. Бубања, Увод у проучавање рецепције поетског опуса Џона Дана, Наслеђе 6, 121-132.

Елиот 1963: Т. С. Елиот, Изабрани текстови, уредник Зоран Гавриловић, Београд: Просвета.

Јерков 2010: А. Јерков, Хазарски вилајет, у: зборник радова Павићеви палимnсести, Бајина Башта: Фондација Рачанска баштина, 139-154.

Јовић 1996: Б. Јовић, Поетика Милоша Црњанског - два страна утицаја, у: (ур. М. Шутић) Милоши Црњански: теоријско-естетички приступ књижевном делу, Београд: Институт за књижевност и уметност, 77-87.

Кирилова 1996: О. Кирилова, Дом и бескућништво код Андрића и Црњанског, у: (ур. М. Шутић) Милош Црњански: теоријско-естетички приступ књижевном делу, Београд: Институт за књижевност и уметност, 89-93.

Ламонт 2000: Rosette C. Lamont, Coma versus Comma: John Donne's Holy Sonnets in Edson's WIT, The Massachusetts Review, Vol. 40, No. 4, 569-575. 
МекКероу 1927: Ronald В. McKerrow, An Introduction to Bibliography for Literary Students.

Милић 1996: Н. Милић, Зарез Црњанскога (2): Естетика запете, у: (ур. М. Шутић) Милош Црњански: теоријско-естетички приступ књижевном делу, Београд: Институт за књижевност и уметност, $57-67$.

Пауновић 2012: 3. Пауновић, Милош Црњански и енглеска књижевност, Анали Огранка САНУ у Новом Саду, бр. 8, Нови Сад: Огранак САНУ у Новом Саду, 20-31.

Петковић 1996: Н. Петковић, Лирске епифаније Милоша Црњанског, Београд: Српска књижевна задруга.

Редпат 1967: Theodore Redpath, The Songs and Sonnets of John Donne, Methuen and Co. Ltd.

Симпсон 1928: Evelyn M. Simpson, A Note on Donne's Punctuation, The Review of English Studies, Vol. 4, No. 15, 295-300.

Смит 1971: A. J. Smith (ed.), John Donne: The Complete English Poems, Harmondsworth: Penguin Books ltd.

Стингер 2000: Gary A. Stinger (general editor), The Variorum Edition of the Poetry of John Donne, Vol. 2, Bloomington \& Indianapolis: Indiana University Press.

Хејворд 1936: John Hayword, John Donne, Dean of St. Paul's Complete Poetry and Selected Prose, London and New York: The Nonesuch Press and Random House Inc.

Црњански 1973: М. Црњански, Моји енглески песници - Џон Дан, Кюижевне новине XXV (16. 03. 1973).

\section{ИЗВОРИ}

Дон 1981: Џон Дон, „Опроштајна реч: о мом имену на прозору”, Предавање о сенци, превео и приредио Душан Пувачић, Бањалука: Глас.

Црњански 1992: М. Црњански, Испунио сам своју судбину, приредио Зоран Аврамовић, Београд: БИГЗ, СКЗ, Народна књига.

Црњански 2004: М. Црњански, Роман о Лондону, приредио Мило Ломпар, Београд: НИН, Завод за уџбенике и наставна средства.

Црњански 2008: М. Црњански, Есеји, приредио Мило Ломпар, Београд: „Штампар Макарије”, Подгорица: Октоих. 


\title{
ПРИРУЧНИЦИ
}

Вујаклија 1980: Милан Вујаклија, Лексикон страних речи и израза, Просвета: Београд.

\section{PARASLAVISTICS: PUNCTUATION, DONNE AND CRNJANSKI - LOVE WITHOUT GENERATIVITY}

\begin{abstract}
Summary
The paper probes possible traces of the poetry of John Donne in the poetry and prose of Milos Crnjanski, within, but also against, the methodological framework of parallel studies of Anglistics and Slavistics, or the "paraslavistics". Bearing in mind Crnjanski's well documented fondness for Donne's poetry, as well as the established syntactical peculiarities of the poetry of both, the paper especially aims to establish parallels in terms of the way in which the two poets punctuate their texts. By way of a conclusion, the paper comes up with its own summary suggesting that the punctuation of Crnjanski can be read as in fact opposed to the punctuation of Donne, which might also be an initial stab at the general problem of the way in which the results of comparative studies become imprisoned by their aims, and pushed into circular reasoning.
\end{abstract}

Keywords: punctuation, coma, paraslavistics, Donne, Crnjanski

Nikola M. Bubanja Časlav V. Nikolić 